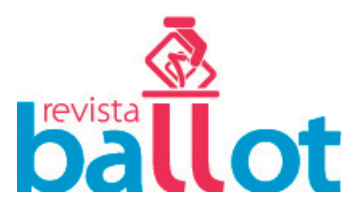

\title{
Regulating nominations in political parties: Candidates, open primaries and Law
}

\author{
Miguel Pérez-Moneo (Universidade de Barcelona, Espanha) \\ miguelperezmoneo@ub.edu \\ Derecho Constitucional y Ciencia Política \\ Av. Diagonal 684 \\ 934035554
}




\begin{abstract}
:
Candidate nomination is in the core of any democratic order. Political parties require an efficient nomination process that should achieve three goals: 1) determine a clear winner, 2) promote a capable politician and 3) prevent the negative effects of internal competition. In order to regulate this process, the interests of all the agents involved have to be balanced. Particularly, the interest of the affiliates, who would want to exert some control over the process and the candidate selected; the interest of the party as-an-organization, who would like to select a competitive candidate; the interest of the candidate-to-be, who would like to know beforehand the procedural aspects of the nomination; and, last but not least, the interest of the electorate, that would like to participate in the elaboration of the electoral ticket. Taking into account that in countries such as Spain, Italy or France, nomination is a non-state-regulated process, political parties have a wide margin of appreciation when regulating this process. Analyzing former primary processes (French PS and Italian PD) and regulation proposals (Spanish PSOE), this work aims to study the basic aspects on regulating nomination by the political parties. Therefore this paper will address when to conduct the nomination process, which organ of the party can take the decision and regulate the process, who (and how) can be candidate, who composes the selectorate, how do the selectorate express their preferences, and how the process is financed. The results obtained will determine the internal requirements that political parties impose on the right to be a candidate in a formal electoral process, underlining their important role in a representative democracy.
\end{abstract}

Keywords: Political parties; Nomination process; Open primaries; France; Italy; Spain; Parti Socialiste; Partito Democratico; Partit dels Socialistes de Catalunya

\title{
Regulação de nomeação de candidatos por partidos políticos: candidads, primárias abertas e direito.
}

\section{Resumo:}

A nomeação de candidatos é tópico central de qualquer ordem democrática. Partidos políticos requerem um processo de nomeação eficiente que deve alcançar três objetivos: 1) determinar de forma clara um vencedor, 2) promover um político capaz e 3) impedir os efeitos negativos da competição interna. Para regular esse processo os interesses de todos os agentes envolvidos devem ser postos em equilibrio. Especialmente os interesses dos filiados, que almejam exercer algum controle sobre o processo e o candidato escolhido; o interesse do partido enquanto organização, que almeja selecionar um candidato competitivo; o interesse do pré-candidato, que almeja saber de antemão os aspectos procedimentais da nomeação; e, finalmente, 0 interesse do eleitorado, que almeja participar na elaboração das candidaturas (electoral ticket). Ao se levar em conta que em países como Espanha, Italia e França a nomeação é um processo não regulamentado, partidos políticos têm uma larga margem de autonomia ao regular esse processo. Analisando eleições primárias passadas (do Parti Socialiste francês e do Partito Democratico Italiano) e propostas de regulamentação (do partido espanhol PSOE), este trabalho objetiva estudar os aspectos básicos da regulamentação da nomeação de candidatos por partidos políticos. Dessa forma, o trabalho indicará quando deve ser conduzido o processo de nomeação, qual órgão partidário pode tomar a decisão e regular o processo, quem (e como) pode se candidatar, quem compóe a convenção partidária (selectorate), como a convenção expressa suas preferencias e como o processo é financiado. Os resultados obtidos determinarão os requerimentos internos que os partidos políticos impóem ao direito de se candidatar em um processo eleitoral formal, sublinhando seu importante papel na democracia representativa.

Palavras-chave: Partidos políticos; processo de nomeação; primarias abertas; França; Italia; Espanha; Parti Socialiste; Partito Democratico; Partit dels Socialistes de Catalunya 


\section{INTRODUCTION}

Candidate nomination is in the core of any democratic order as the selection of electoral candidates is a fundamental activity in the political process. Through the nomination process, political parties exercise the political recruitment function and, at the same time, act as a filter for future members of Parliament. In fact, the composition of the Parliament is determined by the political parties in two different ways (Gallagher, 1988b): on one hand, they determine the profile and personal characteristics of the members of Parliament when establishing who can enter the electoral competition. On the other hand, those who select the candidates have a deeper impact than voters in the composition of the Parliament, even deeper when the electoral system does not allow the voters to express their preferences over the electoral ticket (Ranney, 1965). That happens when the vote is expressed through blocked and closed electoral lists, where the one that determines the composition and the order of the list is the one that choses indeed the members of Parliament.

Besides, even though nomination can be seen as an internal matter of a party, it falls within the process of political representation and directly linked to the political participation of citizens (Katz, 2001). Nowadays, the nomination process and the conformation of the electoral ticket are the most important public functions that political parties perform (Kirchheimer, 1966). And the way in which political parties select their candidates is a test of how democratically they conduct their internal affairs (Gallagher, 1988b), to the extent that it can be said that he who controls the nomination process, is the owner of the party (Schattschneider, 2004). Irony can be detected when certain party executives say: "let them vote until their stomachs ache, but do not let them decide anything" (Christensen \& Kirkpatrick, 1950).

Last, but not least, on the access to the electoral competition, three moments should be distinguished: 1) the individual decision to run in an election; 2) the decision of the party to present this person as a candidate in its ticket; 3 ) the inclusion on the electoral ticket, once all the legal requirements have been checked. That means that the right to stand as a candidate is exercised through - or despite - the political parties. So a "due process" to become a candidate is needed in order to guarantee this right.

Political parties require an efficient nomination process that should achieve three goals (Ceaser, 2004): 1) determine a clear winner. That means that the winner should be uncontested and capable to embody the party message and identity;2) promote an able politician, with electoral appeal and abilities to perform the public office; and 3) prevent the negative effects of internal competition, as the allocation of scarce commodities within the party will often be a point of conflict (Katz, 2001). The internal procedures shall promote a balance between the ambition of the contestants and a behavior that enhances the common objectives.

Political parties are competitive organizations and their survival depends on achieving electoral success. It is observed that party discipline is strengthened before the elections at the expense of democratic practices (de Vega García, 1989). So, normally, they act in order to maximize the votes they receive or can receive (Martinez Sospedra, 1996). In the electoral campaign, political parties must convince the voters that they will be able to articulate and represent their interests and transform into facts the promises they make. They need to act with internal cohesion and unity in order to be perceived as a solid and serious option, in the first place (Flores Giménez, 2000). But, also, to be able to use all the means in the party to achieve the electoral victory, in second place (de Vega García, 1989). Electoral competition 
requires a firm hand, as some questions need a quick or immediate answer, which can only be provided when the leadership is clear and uncontested (Navarro Méndez, 1999).

Not only the electoral competition increases party discipline, as well the increasing role of media on political life contributes to the identification of the party with a few candidates and to the centralization of the electoral message and image of the party (Montero \& Gunther, 1994), so the electorate won't be confused and will identify correctly whose electoral offer is it. Taking a look at the nomination processes, it can be said that they have been turned into spectacles and aimed to the general audience, more than become a meeting point between party program and party candidates (Hazan \& Rahat, 2010)influences the balance of power within the party, determines the personal composition of parliaments, and impacts on the behaviour of legislators. In short, it is central to politics in any representative democracy. $\ln \backslash \mathrm{n}$ $\ln (4$. These situations can lead to the personalization of politics, which, at the same time, can produce a shaft of power and, therefore, a counterbalance. Normally, in parliamentary democracies parties rather than persons get the mandate. Personalization presidentialization of politics would create a puzzle of political representation and electoral democracy (Wagner $\&$ Weßels, 2012). In this sense, it is feared that a parliamentary system will move into a "presidentialized" system, with an executive with an increased power and legitimacy.

Taking into account that political parties are supposed to provide with candidates the public offices, they are expected to behave as democratically as any other public agency. Unfortunately, they are used to invoke their private status as associations to avoid public controls, assuming that nomination and other activities are just "internal affairs" (Maroto Calatayud, 2008). Democratizing political parties will help to limit the true sovereign ${ }^{80}$ and to improve the representation canals, as it would help to keep in touch the owner of the sovereignty and the exercise of this kind of power (Rescigno, 1982). Democratizing their internal procedures would help, as well, to increase the independence and autonomy of the members of Parliament from the party leaders and their responsiveness in front of the citizens (Katz, 2006); and is also required in order to maintain the representativeness of the modern Parliament (Pinelli, 1984). Although political theorists of representative government of post WWII relayed in the idea that democracy had to be found in the competition between parties, not within them (Barberà, Baras, Barrio, \& Rodríguez Teruel, 2008), just a pluralism of parties is not enough to guarantee the division of power: to limit the power of each party and to empower the party members are needed. ${ }^{81}$

80. "[N]egli stati democratico-pluralisti, e comunque in Italia, il luogo della sovranità sta nel sistema dei partiti. I partiti, che sono l'effettivo sovrano empiricamente verificabile, si presentano invece come i modesti interpreti del "vero" sovrano, che ideologicamente viene dichiarato essere il popolo" (Rescigno, 1984).

81. “Se (...) la concorrenza non si possa più realizzare mediante costituzione di nuovi partiti - ci versi quindi in una condizioni di oligopolio politico - la garanzia della concorrenza e della libertà politica si deve trasferire all'interno dei partiti, mediante il riconoscimento di diritti di accesso, di elettorato attivo e passivo, l'applicazione del principio di maggioranza, ecc. Avviene così che il metodo democratico resta l'abito della democrazia interna" (Pedrazza Gorlero, 1992). 


\section{Legal or internal regulation?}

How are nomination processes regulated? The importance of this function - the configuration of the electoral offer - make one think that these processes should be regulated by law or, at least, should have taken the attention of the legislator (Norris, 2006). However, Political Science has observed that in most of the democracies, nomination, as other issues related to political parties, is not taken into consideration by the law (Ranney, 1965). And, moreover, nomination usually takes place out of the knowledge of the electorate. Due to its secrecy, nomination processes have been known as the "secret garden of politics" (Gallagher $\&$ Marsh, 1988; Hazan \& Rahat, 2006; Ranney, 1965).

In order to regulate this process, the interests of all the agents involved have to be balanced. Particularly, the interest of the affiliates, who would want to exert some control over the process and the candidate selected; the interest of the party as-an-organization, who would like to select a competitive candidate; the interest of the candidate-to-be, who would like to know beforehand the procedural aspects of the nomination; and, last but not least, the interest of the electorate, that would like to participate in the elaboration of the electoral ticket.

Depending on the attitude of the State towards nomination, three legal models can be found (Barrat i Esteve, 1995):

- Indifference towards the nomination process (the vast majority)

+ Public intervention:

- Establishing principles, more or less broad, that parties can follow when regulating internally their nomination processes

- Regulating the whole nomination process and even organizing and funding these processes.

The first attitude can be named as "realistic"; the second and third ones as "legalistic". A realistic attitude comes from the idea that law cannot regulate the inner activity of a party, either because it won't be obeyed, or because the interior of a party is an area that the power of the State cannot reach. If the Law does not regulate the nomination process, that means that each party statute has to take into consideration the nomination process and establish its rules (Rahat \& Hazan, 2001; Ranney, 1981). And, therefore, the right to stand as a candidate will be regulated by the political party. This ability of the party falls within its right to association, which includes the right to establish its own organization. And it has a wide margin of appreciation to regulate this process.

However, letting the parties regulate the process of nomination can generate some problems. The biggest one, from my point of view, would be the lack of legal certainty, as it's likely that the internal regulation of political parties will be too flexible and easily changeable ( $\mathrm{Ha}$ zan $\&$ Rahat, 2006). If the rules are not clear, he who apply it or interpret it will decide the rules themselves.

Besides, the way the parties select their candidates is a parameter of their democratic functioning (Bille, 2001). And if internal democracy is detrimental to the political parties and their political or electoral objectives, they will not exert a restraint and adopt democratic procedures. Unless the political parties perceive that advantages can come from their democratization, they won't be willing to do so. Is it suggested (Pennings \& Hazan, 2001) that a 
new and democratic model of organization could help maintaining the levels of affiliation or electoral base, as it will transmit the feeling to the members and voters that they decide, that they are part of the party and, therefore, of the political system. To broaden the political rights of the members of the party could be an enormous incentive to bring members in and, moreover, it's almost costless to the political party (Rahat \& Hazan, 2007; Scarrow, Webb, $\&$ Farrel, 2000). If, at the same time, political parties want to make affiliation attractive to non-members, the more rational thing to do will keep the decision-making process within the boundaries of the party, on the hands of the members (Scarrow, 1996).

Deepening the internal democracy within the parties will help them to confront the social movements and to assimilate their vindications and, in this sense, improve the quality of the intermediation between the society and the State of the political parties (López Nieto, 2007).

The legalistic approach, for its part, considers that a Law regulating parties' nomination processes is needed. In the United States, this approach was created around the White Primary Cases, Nixon v. Herndon [273 US 536 (1927)], Nixon v. Condon [286 US 73 (1932)], Grovey v. Townsend [295 US 45 (1935)], United States v. Classic [313 US 299 (1941)], Smith v. Allwright [321 US 649 (1944)] y Terry v. Adams [345 US 461 (1953)]. In the Southern states, the Democratic Party was hegemonic and it was supported, mainly, by the white population. The true electoral contest was the nomination process. The Supreme Court strategy in this cases, in order to guarantee the black population the possibility to participate in the political life of these States, was to found a way to link the inner activity of the parties with a state action. And it made so through considering that the nomination process was part of the electoral process. From these cases, the idea that nomination processes were part of the electoral process and constituted state action was formed. And, therefore, States began to regulate actively the processes that parties must follow to put their members in the electoral ballot. However, this public conception of the inner party procedures began to change in the 80's (Claude, 1970; Epperson, 1986).

Moreover when the Constitutions, as is the case of the Spanish one (art. 6) or the German one (art. 21), require that their internal organization is democratic or that they are bound to the democratic ways when determining the public policies (Italian Constitution, art. 49). These principles or mandates are directed to the Legislator and not directly to the political parties ( $\mathrm{Pi}$ nelli, 1984). Therefore, following this interpretation, a Law about the nomination process won't be invading a protected ambit of the political party. The intervention of the legislator can found another fundament in the public funding of the activities of the political parties, the power of the purse: if the States publicly funds the activities of the political parties, they can retain some power and link this money to a particular objective $\left(\right.$ Galeotti, 1983) ${ }^{82}$.

82. " $[\mathrm{N}]$ on è vero (...) che ciò che accade all'interno dei partiti (...) sia affare tutto ed esclusivamente interno ai partiti stessi (...) se lo Stato contribuisce con i fondi publici, tratti dalle tasche di tutti i cittadini, al funzionamento dei partiti, ciò significa (...) che sussiste un fondamentale interesse publico acchè ciascuno di questi partiti (...) scelga e deliberi, bensì, liberamente e a suo talento (...); ma altresì che faccia tutto questo con metodo democratico, e non con metodi violenti, prevaricanti, fraudolenti, e, con metodi antidemocratici, ossia, in violazione e dispregio dell'equale diritto di ciascuno dei soci di concorre liberamente alla formazione della volontà partitica. Ma, ancora, (...) va recordato (...) che il partito (...) tende (...) a trasfondere il propio ordinamento interno, nella vita e nel funzionamento del sistema politico in generale. Di qui, l'ulteriore interesse che si pone per l'ordinamento giuridico generale di garantire (e così garantirsi) che la funzionalità interna dell'associazione partitica obbedisca e si conformi a taluni inderogabili principi di metodo democratico" (Galeotti, 1983). 
The legislator has to precise the minimum content of the constitutional requirement of democratic organization/functioning. And it has to be a minimum, so the different parties, responding to different ideologies, can exercise their right to auto-organization. Only in the aspects related to a fundamental right, such as the right to stand as a candidate, the Law ought to be imperative. In those aspects, the legislature shouldn't just establish abstract obligations to the parties - it would be the same as not regulating - nor regulate just the formal aspects of the party functioning. On the contrary, the Law shall establish the substantive aspects of the process in order to control the party decisions so they no remain sovereigns. In order to safeguard the public interest, the State has the duty to intervene in the preparatory phase of the electoral system, on the nomination process (Ostrogorski, 1979). Candidate selection is the intersection between Party Law and Electoral Law (Janda, 2005) and, therefore, could be regulated in either of them (Müller \& Sieberer, 2006).

As it has been said, in most of the democracies, nomination is not regulated by Law. For example, in Spain, nor the Party Law nor the Electoral Law establish a word about the nomination process. The latter determines who can be candidate and how the electoral lists must be presented and even that they must be gender-balanced. Consequently, in Spain, nomination is extra-legal.

Exceptions to this a-legal situation are the case of Germany, Norway or Finland, in Europe, and United States, Argentina and Chile in America. It has been said that public regulated nomination processes happen where the party organization is marginal, as it is the case of United States (Epstein, 1981). On the contrary, parties that choose their candidates through their own regulated processes have an organization based on affiliation and membership. This is a tendency that should be studied by the Political Science, and it's starting to change.

The United States of America were the only country where it has existed a complete regulation of the nomination (Hazan \& Rahat, 2006), as a response to bossism and political corruption at the beginning of the 20th Century (Ranney, 1981). The Progressive movement favored the public regulation of political parties and the adoption of primary election (Bott, 1990): "Nominations [were] the focal point of reform efforts because they are the most public and important act performed by a political party" (Epperson, 1986). At the end of the 19th Century (California, 1866; Ohio, 1871) appeared the first laws that established optional procedures that parties could follow to operate their nominations. And in 1903, Wisconsin approved the first law that made compulsory to select the electoral candidates through a primary election.

Argentina has recently approved the Law 92/09, of 2 December 2009, of democratization of the political representation, transparency and electoral equity. This law makes compulsory the selection of candidates through open primaries, that shall be held simultaneously for all the political parties.

Chile has reformed its Constitution on 4 January 2010 and enacted the Law 20640, on December 2012, establishing primary elections for the nomination of candidates to President of the Republic and Majors. In the case of Chile, the primaries are not compulsory, but if the parties decide to use them there is public funding. Besides, the law does not prefer the open primaries, but leaves on the hands of the political party the determination of the selectorate of the candidates.

In Germany, article 17 of the Parteiengesetz requires political parties to select their candidates to the National Parliament either through the secret and direct vote of the members in each constituency, or by a constituency convention, where party members can direct or in- 
directly participate (Ranney, 1981; Roberts, 1988). The German electoral law includes legal provisions relevant to the nomination process. It distinguishes between uninominal and list candidates. The former must be selected by the party members of the constituency, direct or indirectly. The most frequent is a delegates meeting that decides through secret vote, requiring absolute majority on the first round and majority on the second tour. Under the legal regulation, the regional executive of the party could oppose the candidate selected and force the repetition of the process, whose decision would be final (Roberts, 1988). Out of these principles, the party statutes can detail other rules.

In Finland, the Law requires the candidates to be selected through secret vote of the party members from the constituency, through a process that has to be regulated by the political parties. If a political party fails to regulate the process, the law establishes a subsidiary process (Müller \& Sieberer, 2006).

The Norwegian legislator decided to regulate nomination process after a change in the electoral system, when it became proportional rather than majoritarian. Considering that the electoral change would affect the inner life of the parties, the Selection Candidates Law of 1921, revoked on 2002, urged the parties to select the candidates on each electoral district by conventions formed by delegates chosen by the affiliated members of the party. However, the Norwegian Law had an indirect impact, as it established that the organizations that followed this nomination process would receive public funding. In practice, Norwegian parties could choose any other nomination method, but without enjoying public funding (Ranney, 1981; Valen, 1988).

I found the Chilean and the former Norwegian model, where the State offers some advantages - public funding, media exposure - to the political parties that follow the nomination process suggested by the Law the most respectful of the party autonomy and the most incisive with the objective of public participation.

\section{Cases}

Taking into account that in countries such as Spain, Italy or France, nomination is a non-state-regulated process, political parties have a wide margin of appreciation when regulating this process. Analyzing primary processes (French PS, Italian PD, Spanish PSC) the basic aspects on regulating nomination through open primaries can be detected and help some other parties or countries looking for proposals (as Spanish PSOE and ICV).

\section{a) "LES PRIMAIRES CITOYENNES" OF THE FRENCH SOCIALIST PARTY (PS)}

Through the primaires citoyennes, the presidential candidate of the French Socialist party (Parti Socialiste) and the Parti Radical de Gauche (PRG) was nominated. Both parties participated and organized the primaries that were open to other left parties. The French President is elected directly by the citizens in a double-round system.

\section{Regulation:}

The French Socialist party took the decision of organizing open primaries to choose its candidate for the presidential elections 2012. With this decision, they wanted to legitimize the candidate from the bottom of the party and to give their leader a supplementary support. From 1971 to the date, it just had used closed nomination processes, only for members. The 
primary as nomination system was chosen on 1995. After an internal crisis, the party decided to open the primary to the sympathizers. The primaries of 2006 were a success, as they got a lot of attention from the media and modernized the image of the party.

The promoter of the open primaries was a foundation, Terra Nova, that reclaimed the update of the representative relationship. A commission presided by Arnaud Montebourg and in which all the sensibilities of the party were represented made the proposal of primaries, following the principles set by the National Council of the party.

\section{Organization:}

The Comité National d'Organisation des Primaires (CNOP), formed by representatives of all the parties organizing the primaries and representatives of the candidacies, is the body charged with the organization of the primaries. This structure is replicated in each department (Comités Départamentaux d'organisation des primaires). The Comité National d'Organisation des Primaires is an arbitration organ, as well although there has been a guarantee commission (High Authority).

For the scrutiny another committee is formed: there will be scrutiny commissions formed by a representative of each candidate and three people selected by the provincial organization committees.

The open primary was financed by money collected from the voters. The primary cost around 3,000,000€.

\section{Who can stand for election in the primaries?}

A person obtaining the endorsement of $5 \%$ of the socialist Members of Parliament (17), or of the members of the National Council of the party (16), or of the socialist members of Conseil regional or Conseil General (100) from, at least, 10 departments and 4 regions, or of the socialist Majors from cities over 10,000 citizens (16) from at least 4 regions can run on the primary. The High Authority of the primaries will register the candidacies. On 2011, the Socialist Party has eased the possibility to run on the primaries, as in 2006 the requirements were higher (15\%). Therefore, there were more contestants on 2011 (6).

The decision to open the primaries was total, so the PS let other political parties to participate in the primary and, therefore, that contestants could come from the Left, but not necessarily from the Socialist party itself. If other political parties participate on the primaries, they will establish their own rules of endorsement.

Candidates must accept several requirements, such as the role of the High Authority as a single arbitral forum whose decisions are final. Consequently, the candidates must recognize the results proclaimed by the High Authority. As well, candidates must sign a public commitment to support the winner candidate and to participate publicly in his/her campaign. Finally, they have to agree to respect the rules of campaign established by the CNOP, especially about the expenditure limits. Pre-candidates could propose their own political message, but the PS tried to avoid that losers could become sore-losers and detach from the party and create their own electoral platform for the Presidential elections.

To avoid that the two-rounds system twist the aim of the primary and transform it in a bargain, it was requested that candidates should present their program and team, so from the first moment the personality and features of each candidate could be perceived. 


\section{Composition of the selectorate:}

All the citizens who wanted the victory of the Left on the 2012 Presidential election could vote on the open primaries. They had to appear on the electoral list or to proof that they were on the list; they had to be 18 years old between the date of the primaries and the Presidential election; or, they could be members of a political party that participated on the primaries or in a juvenile organization of one of these parties and no fulfill the former requirements (foreigners, minors).

Selectors must sign a statement for the socialist / progressive values and fill in their personal data and pay a euro $(1 €)$. The participation on the primary was massive: 2,665,000 voters on the first round and 2,860,000 on the second round. On the 2012 elections there were over 46,000,000 persons registered to vote.

In order to have a motivated membership, the Party saved a role for the classic member so he/she wouldn't feel like he/she had no participation in the process. The party member could participate in the organization of the primary or as a volunteer on the team of one of the contestants.

\section{Practical aspects of the nomination process:}

Using of the electoral roll: the Electoral roll can be used in France in the primaries, as it is public and political parties can rightfully use it (art. 28 Electoral law). The Minister of the Interior invited the Prefects to send the electoral roll in a computer readable form (Circulaire de 10 janvier). The electoral roll was used to distribute the voters on polling stations and to constitute the primary electoral roll.

For voting places the Socialist Party preferred public places coincident with the ones on Election Day. The Minister of the Interior ruled that City Halls could decide to lend local owned places to hold the primaries and that they could decide to establish a contribution to compensate the use of these locals. Like wise, the City hall could lend the ballot boxes and electoral cabins or even allow city workers to work for the primaries, although the conditions have to be negotiated on each case.

There was an electoral office par 5,000 electors and between 10 and 15,000 electoral offices on total.

On Voting day, personal data was collected on a voluntary basis: the PS proposed to the selectors to leave their email or telephone number in order to be informed of the party activities.

\section{Calendar}

A national office of the party fixed the definite calendar almost ten months before the nomination process began. Runner-ups could present their candidacies from June 2011 to Fall 2011. The primaries lasted for six months, with an eventual second tour 15 days after the first round.

They were organized months in advance the general election, although not too soon, as this was a mistake in the 2006 primaries, when the candidate selected had no time to organize her political campaign.

\section{Political campaign}

Candidates, campaign team members and party members who volunteer could participate in the political campaign. In fact, each candidate created his/her own association with the status of political movement and subjected to the same rules about funding that the political parties. That 
means that it could receive donations but only from natural persons and under limitations: not more than 75,000€ per person and year and no more than $150 €$ on cash (in this case are considered anonymous donations). On top of that, each candidate from the PS received 50,000€ from the party to conduct his/her campaign. And some other incomes in kind: an office, a press-conference room, a car and a card to pay for gas and highway tolls. The candidate coming from the PRG had his own party to collect donations and to use its resources.

The pre-candidates had to send the Commission nationale des Comptes de campagne et des financements politiques an extract of their expenses, although only the expenditure made to promote the nominee will be taken into account as an electoral expenditure (Commission nationale des Comptes de campagne et des financements politiques).

The parties who co-organize the primaries are compelled to spread the political communication of all the candidates to their members and supporters/voters.

The political campaign had to be constructive and loyal, centered on ideas and proposals. Negative campaign was forbidden and the High Authority could solve a conflict between candidates. Two debates were held on national TV. One on the first round and a second one before the second round, between the two final contestants.

\section{How does the selectorate express its preferences?}

The voters used paper ballots and scrutiny was manual. The first scrutiny was on each polling station and vote tabulation was made by a regional commission formed by one representative for candidacy and three people chosen by the Comités Départamentaux d'organisation des primaires.

\section{Formal act of nomination?}

The High Authority proclaimed the selected candidates. A formal act of nomination was considered, to end the primaries and visualize the support and unity of the party towards the candidate. In order to reinforce cohesion, after a candidate is proclaimed, the CNOP will design the type of support that every other candidate must deliver. In this sense, the CNOP will define the strategy of communication of the non-elected candidates towards their supporters and the way they will engage on the presidential campaign. Each non-elected candidate will participate actively on the appointment/nomination convention.

\section{b) “ITALIA. BENE COMMUNE 2012” PRIMARY ELECTIONS}

Through the primaries 2012, the leader or the Left Coalition "Italia. Bene Comune" was chosen. The Partito Democratico (PD), Sinistra Ecologia Libertà (SEL) and the Italian Socialist Party formed this coalition. This position involves being the candidate for Prime Minister. The Italian Prime Minister is proposed by the Italian President, but has to receive the confidence of both Houses of the Parliament.

This case is an example of how primaries are not consistent with parliamentary systems: Pier Luigi Bersani won the nomination and the "Italia. Bene Commune 2012" won the legislative elections. However, he could no become Prime Minister as the Senate wouldn't give him its confidence. Another member of the PD who did not concur to the primary replaced him. Nowadays, the loser of the second round of the primary is the Prime Minister. There has not been a binding result of a primary and it has made evident that is the Parliament who elects the Prime Minister and that is not conditioned by the result of the primary. 


\section{Regulation:}

The PD President (Segretario) decided, during an executive meeting in June 2012, to establish the primary as the system to choose the candidate of the Left Coalition Italia. Bene Comune on the election 2013. The primary was thought to serve as a nomination process but also to promote and make more dynamic the public life of the country. The decision was confirmed by the Assembly of the party on July, and gave a mandate to the President to regulate the process together with the other two parties of the coalition, establishing the principles that should rule the nomination process.

The Board of Appeals (Il Collegio dei garanti), the body created to rule the process, approved the regulations on 2012 after consulting the participating parties.

\section{Organization:}

The Board of Appeals is the main body on the organization of the primaries, as it has the ability to interpret the regulations. It regulates the process, but also is competent to monitor the conduct of the contestants and assure the regularity of the outcome. It is the body that proclaims the results and the nominee and resolves any dispute about the results. As its name suggests, it works as Court of Appeals on the rest of the controversies.

The Board of Appeals appoints the Coordinating body (Il Coordinamento). It is composed of four persons from the participating parties on the primary and a delegate for each candidacy. Delegates can observe, but not decide. The Coordinating body promotes each phase of the process, monitors the primary organization and decides on the first stage the controversies occurred on developing the primary process. It establishes the number of voting places and allocates them, prints the ballots and provides all the material needed to vote. As well, the coordinating body coordinates the provincial organization, explaining the regulations when they are not clear. This body turns into Electoral Commission once the voting is finished and carries on the scrutiny.

The electoral offices are composed by two persons and have the mission to collect the money, the registration and the adhesions to the Public Commitment.

Almost 6,000,000€ were collected from the participants. With this money the expenses of the organization were paid (over 1,8000,000€, where communication expenses were the lion's share) and there was money allocated to the electoral campaign of the coalition.

Candidates could raise money, but they had to communicate to the Board of Appeal every donation over $500 €$ they received. Besides, at the end of the primary, they had to give a copy of the documentation related to incomes and expenditures on the primary.

\section{Who can stand for election in the primaries?}

To access the primaries, pre-candidates had to collect 20,000 endorsement signatures from center-left voters. Of these signatures, there couldn't be more than 2,000 from the same region. There were six weeks to collect the signatures. Members of the PD had special rules and to run in the primaries, a member of PD other than the President must present signatures of $10 \%$ of the components of the Assembly of PD (96) or, at least, 3\% of the party members on the 2011 census (18.000). There were five candidates on the primaries, three of them from PD.

Every pre-candidate must accept to respect the results of the primary and to faithfully collaborate with the candidate chosen during the electoral campaign and along the legislative term. 
The contestant's code of conduct was approved by the Board of Appeal and was inspired by the principle of common responsibility, reciprocal rightfulness, transparency and sobriety.

\section{Composition of the selectorate:}

Any citizen complying the requirements to vote on general election, minors turning 18 years old just before the Voting day, European citizens living in Italy and foreigners with residence permit living in Italy can participate in the primary. They have to sign a public commitment to the coalition, an agreement to electorally support the coalition and register to vote. In the moment of the registration, they have to pay at least two euro $(2 €)$. The register will be open for 21 days before the Voting day. In the electoral offices the voters will receive an "electoral certificate" that they must show on Election Day.

To vote on Voting day, the selectors have to show the officials their identity card, their polling card and the "electoral certificate".

On the second tour only the voters on the first round could vote. However, the Board of Appeals decided to change the rule after the first round, in order to allow the participation of those who were registered to vote before the first round and of those who, for any cause, couldn't participate on the voting on the first round.

At the end, there were $2,808,662$ voters on the second round of the primary, being $47,000,000$ registered voters.

\section{Practical aspects of the nomination process:}

There are almost 9,239 voting places. To avoid people voting more than once, they used the electoral certificate to mark the persons who had voted.

\section{Calendar}

The Board of Appeal fixed the date of the primary after an agreement between the leaders of the participating parties. The first round was held on November 25th 2012 and the second round a week after, on December 2nd.

\section{Political campaign}

The campaign must be ruled by the principles of sobriety, transparency and respect between the contestants. A televised debate between the five candidates was held.

The principle of sobriety forbade the possibility to hire paid advertising, nor in mass media nor in the streets

\section{How does the selectorate express its preferences?}

The voters used paper ballots where they crossed the candidate they wanted. They could only vote to one candidate and the electoral formula was first-to-past-the-post. In order to select the most representative and unifying candidate, to win the primary on the first round a $50 \%$ plus 1 of the ballots is required. If not, there would be a second round between the two candidates with the highest number of votes. The winner will be the contestant who gets the highest number of votes. 


\section{c) “LES PRIMARIES OBERTES” OF SPANISH PARTIT DELS SOCIALISTES DE CATALUNYA (PSC)}

The open primary elected the candidate for mayor of Barcelona of the PSC. The City Hall Council elects Majors in Spain. In this sense, the Major election is parliamentary based, although there is no possibility to call for elections before the four-years term ends. However, there is a presidential bias, as the Major has had to head the electoral list of the party that proposes him.

It is the first time that a political party with parliamentary representation has held an open primary in Spain and it has generated a lot of interest as Spanish Socialist Party (PSOE) has decided to use the open primary on 2014 to choose its candidate for Prime Minister.

In Spain, in the national ambit, only two left parties (or party families) - PSOE and IU have conducted primaries. The Spanish Socialist Party held a closed primary in 1996 to elect Felipe González's successor. Unfortunately, the Party was not prepared to have two leaders (the electoral candidate and the Secretary of the party) and the candidate resigned before the elections. The former Communist Party, Izquierda Unida, held non-binding primaries on 2007, although the decision of who would be the candidate was of the Federal Assembly. The exception to closed primaries has been the PSC (Catalonian branch of PSOE) and ICV (the Catalonian branch of IU), both non-state wide parties. In 1999, the PSC organized in 1999 a primary election with just one candidate, but opened to all voters. ICV has a tradition of closed primaries, although not always contested. It has decided to open its primaries to their registered sympathizers (Barberà \& Rodríguez Teruel, 2012).

\section{Regulation:}

The highest executive body of the local branch of the PSC between Assemblies (Consell de Federació) has approved the regulation for the open primary. In order to get to this regulation, a public discussion was held on the University and some private forums.

\section{Organization:}

Two bodies were created ad hoc for the organization of the primaries: a High Authority and an organizing commission. The High Authority is composed of 5 persons: a member of the Board of Appeals of the PSC, two members of the party and two citizens known by their professional trajectory. The High Authority acts in an impartial manner and supervises the nomination process and assures the neutrality of the party bodies. At the same time, it resolves the complaints and challenges presented by the pre candidates. The decisions of the High Authority are finals.

The Organizing Commission is formed by the Secretary of organization of local branch of PSC, two members of the executive body, a member of each of the local branches in the city, a member of each of the sectorial bodies, a member of the juvenile organization and a person of each candidacy. The Organizing commission must act neutral the whole process. It is the body charged with the whole organization of the primary process, including the Voting Day, it has to guarantee the neutrality of the party and give information about the development of the primary to the public, report any breach of the regulations to the High Authority and monitor the campaign.

The Organizing Commission provided the resources to organizing Voting day and the informative campaign that include posting all the selectors registered the information of the candidacies and the general information of the process. 
Thirty voting places were previewed, composed by three persons each.

The primary was supposed to be funded by the contribution of the selectors, a percentage of the donations collected by the candidates and a contribution of the party. Finally, the party took care of the biggest part of the budget. The primary cost around $150,000 €$ and the party provided 110,000€. Pre-candidates collected around 19,000€ in cash.

\section{Who can stand for election in the primaries?}

To become a candidate, one must present the endorsement between 18 and 25 members of the Barcelona PSC Council or between 150 and 200 signatures of members of PSC in Barcelona or even signatures of citizens (between 1000 and 1500). The pre-candidates had 6 weeks to collect endorsement signatures. To start the collection they have to register before the High Authority and commit to the transparency and validity of the process and sign a commitment of loyalty to the primary process and their results.

Establishing a minimum and maximum threshold of endorsement signatures has been seen as a measure guaranteeing the maximum participation and competitiveness, as avoids one candidate coping all the endorsements possible.

The High Authority supervised the endorsement process and verified the validity of the signatures. Once certified the validity of the signatures, the High Authority proclaimed the pre-candidates. Five people concurred the open primary.

\section{Composition of the selectorate:}

Members and sympathizers of PSC could vote on the primary. The membership census was closed two months before the primary. Besides, any person older than 16 years old living legally in Barcelona could participate. In this case, selectors do not coincide with voters, as only nationals and just some foreigners older than 18 years old can vote in local elections in Spain.

To participate, a selector will have to sign a commitment with the progressive values and the electoral success of PSC and to pay at least one euro (1€). If the selector wants, he/she could register and give his/her personal data.

The participation did not fulfill the expectations. 7,463 people voted on the first round and 5,534 people on the second round. The total population registered to vote on 2011 was $1,163,000$.

\section{Practical aspects of the nomination process:}

The pre-candidates had equal access to the party premises and developed their political campaign along the principles set on a Chart of Rights to the information established by the Organizing Commission.

\section{Calendar}

The Executive body of the PSC established the calendar of the primary.

\section{Political campaign}

The political campaign lasted for four weeks. The electoral expenses were borne by each candidacy, with an expenditure limit of 50,000€. Each candidate could contribute with a maximum of $10,000 €$ and donors could contribute with a limit of $500 €$, not counting the contributions in kind. 
Each candidate must present a relation of incomes and expenditures and donations over $100 €$ will be public.

For campaigning each candidate could use the party premises and the communications infrastructure of the party, at their own cost.

Candidates can hire paid advertising on mass media and will have to participate in the debates organized by the party and won't participate in debates where other contestants are not invited.

\section{How does the selectorate express its preferences?}

The PSC adopted a majoritarian double-round electoral system. However, the second round could be avoided if any contestant obtains $40 \%$ of the votes and 10 points more than any second runner. This decision has been criticized, as doesn't allow the typical bargaining of a two-round system and jeopardizes the legitimacy of the winner.

\section{d) BASIC ASPECTS ON REGULATING NOMINATION}

Although there are a lot of ways to select candidates, such as direct access to the ballot, electoral committees, assemblies or conventions, a trend towards the primary election is detected. For example, in Argentina and Chile, where they are legally regulated or in other countries, such as Spain, Italy or France, where nomination is a non-state-regulated process and political parties have a wide margin of appreciation when regulating this process. The "party primary" method is used widely in Belgium, occasionally in Germany, and by the Liberals and SDP in Britain (Gallagher, 1988a). Therefore, I will center my paper in the regulation of primary elections, although some of the considerations could be applied to others ways of nomination.

Regardless of whether the nomination process is regulated by Law or by the political party, there are some basic aspects that have to be taken in consideration. The aim of this section is, consequently, point out these basic aspects and how have they been treated by the experiences mentioned above.

\section{Regulation:}

Who regulates the process? In case the primaries are regulated by the political party, which organ of the party takes the decision? Is there any kind of participation of the membership in the decision? Does the executive of the party just decide the procedure and let it be developed as established? (Ware, 2004) West European countries regulate their own candidate selection process, and therefore have a greater chance of keeping the process under control.

\section{Extent of the decision: who is selected?}

Is the use of primaries advised whatever the political system or the electoral system? While they are not disputed on a presidential system, as they serve to select the Presidential candidate, they are more problematic in a parliamentary system, where the President or the Prime Minister is elected by the Parliament. In this case, the result of the primary election should not be binding, as the decision belongs to a constitutional organ and the decision falls within the extent of a fundamental right of the members of Parliament, who are competent to elect the President/Prime Minister. If primaries are held, they have a political sense, although they could create a problem when negotiating a coalition government. 
This problem can be addressed from another angle: the electoral system. Primaries do not create a problem in a majoritarian (and uninominal) electoral system (Rossi \& Gori, 2009), and they could even be recommended in a proportional electoral system, when the electoral lists are closed and blocked. As electors don't have a real chance to determine nor the composition, nor the order of the electoral list presented by the political parties, the use of primaries will increase their ability to participate in the public issues (Fusaro, 2003; Gambino \& Moschella, 1997; Rossi \& Gori, 2009). Even if the electoral list is not blocked, and therefore the voter can determine the order of the candidates, primaries may have a utility. On the contrary, when the lists are open and every voter can compose his or her own electoral ticket, primaries do not make sense (Fusaro, 2003), although political parties may want to use them to choose the candidate they will endorse.

If the electoral system is proportional and the lists are open, it is important to know who decides the distribution of candidates, that is, how many candidates will run for public office and in which districts. This decision could avoid vote dispersion and help to concentrate the electoral strength in a few candidates.

Proportional electoral systems represent another problem for the primary election. If just the head of the list is chosen by the primaries, which relationship does he or she have with the rest of the list? Can he or she select the rest of the list? Or, at least, enough members as to compose a working team if elected?

\section{Organization:}

Which organ of the party does organize the primaries? Who decides whether the process is conducted or not? Who takes in charge the organization? How are the primaries organized? Are public polling stations used? Which is the ratio selectorate / polling stations? Who forms the scrutiny commission? And the guarantee commission? Which standards of transparency are used? How is the process financed?

Probably, the most relevant question for a party is how the nomination process - above all the fancy ones - is going to be funded. Some countries have adopted public funding for some kind of nomination process. Others ignore this aspect.

If private funding is needed, electoral funding laws may apply and some restrictions can be enacted. In these cases, besides, candidates may have to search their own funding. For example, in pure primaries candidates are rather autonomous from the party, not only in the electoral programmer but in the funding. In some cases, political parties require the candidates to donate a percentage of the money collected to the organization of the primaries.

In mixed primaries, political parties give the contestants funding, normally in kind, resting neutral in other aspects. Mixed primaries shade one relevant aspect on the competition: the capacity of the contestants to obtain support to mobilize a external resources.

The prevision of an internal reclamation procedure is most relevant in order to achieve a legitimate candidate (and unopposed), but also to guarantee party's autonomy, as it will solve their internal affaires without resorting to the judiciary.

\section{Who can stand for election in the primaries?}

Political parties seek for a minimum of seriousness in their internal competition and to obtain a clear and legitimate winner who won't disperse the vote of their electors. With that aim, they normally adopt some requisites to stand for election in the primaries, that go from the 
plain will of an affiliate or the payment of a deposit or a fee to the endorsement of members of the executive bodies of the party or signatures from other party members. Even more, is it possible for a political party to open its competition to aliens or to members of other parties? The latter will happen when both parties agree to choose a common candidate through a primary election or when the electoral system allows one candidate to run for different political parties.

When signatures or endorsement are at stake, the proportion of signatures or endorsement has to be big enough to demonstrate the seriousness and support of the proposal and moderate enough as not to complicate the competitiveness of the process (Ostrogorski, 1979).

To ease the competitiveness of the primaries, political parties could remove the prohibition of multiple endorsements. I don't share this limitation, as endorsing a pre-candidate has a different meaning that voting for him or her, as the endorsement just implies that one agrees to the pre-candidate to enter the competition, not necessarily a political support statement. Furthermore, the endorsement does not necessarily coincide with the vote, which is secret.

It has to be clarified by the primary regulation who registers and announces the official candidates to the primary and if this decision is final or can be challenged.

Political parties electorally oriented tend to establish requisites to access the competition very inclusive, while ideologically oriented parties tend to be more exclusive, in order to guarantee that the resultant candidate has interiorized the party culture (Hazan \& Rahat, 2010). In this regard, most of the parties consider that pre-candidates or participants in the primary ought to be members of the party, with all his or her financials duties fulfilled. Furthermost, additional requisites can be imposed, as a minimum seniority, to have served in the party or in another public office or not to have held office (Freidenberg \& Sanchez Lopez, 2002). However, not all the requisites are formalized as what is usually taken into consideration is the dedication of the pre-candidate to the party, his/her track records in the district or in the party organization or his/her electoral appeal (Gallagher, 1988a).

All this considerations, however, fall apart when the internal regulation of the political party allows independent or non-members candidates to the primary. In these cases, political parties can adopt additional requisites, such as compulsory affiliation to the party, to sign a commitment to vote for the party and electorally support it or even the condition that the contender cannot participate in the activities of another political party (Federal Electoral Commission, 1988).

If the internal competition is between members of the same party, primaries can help to solve an internal conflict that cannot be solved by other means. Another possibility is that the primaries have as contestants party members that belong to different and clearly identified party factions or political parties inside a political coalition. In this case, primaries will help finding the candidate that best represents the party or coalition as a whole and, therefore, the most representative sector. If that's the case, the competition will have an ideological and identity character, in which a tough competition could lead to a weakening of the party or the federative/coalitional links. Lastly, it can happen that the dispute is between individuals not marked, who can even not be party members. What is sought in this case is finding who can represent the party as an organization, what usually happens when the party is not structured or has a weak organization. The legitimacy of the winner will depend on the level of participation.

Finally, it can be brought to consideration the necessity of the representation of minority or underrepresented groups within the party. To this end, two mechanisms could be used, such as the establishment of a quota or the creation of a specific constituency for this collective (Hazan \& Rahat, 2006). 


\section{Composition of the selectorate:}

The decision about who participates and who does not in the nomination process is one of the most powerful selective incentives that a political party has (Olson, 1986). There is a wide variety in selectorate composition in European parties. This diversity can be explained by referring to the complex interactions between national laws, intra-party decision-making and the electoral fortunes of parties. The more parties are weakened by the loss of members and/or vote, the stronger the incentives will be to open up the process of candidate selection (Pennings \& Hazan, 2001). Normally, in most of the European countries the nomination process were not opened to the electorate, as the political parties are based on membership and member-based nomination processes allow a more intense control over the result. This is a consequence of the cartel party, which has led to the professionalization of party leadership, where there's only a limited class of inside participants. Anglo-Saxon parties tend to have more open selection procedures than those common in Western Europe, although some major European parties are opening up their procedures. Within the European context, the Scandinavian tradition of candidate selection appears relatively open and decentralized. In UK, when the Labor party has opened its nomination process there has been a power shift from the Parliamentary caucus to the organization of the party, including the local-level organization (Dalton \& Wattenberg, 2000).

If party members compose the selectorate of the nomination process, the relevant would be who belongs, actually, to the party. Party internal regulation defines who can be considered a member of the party and how can one adhere. It is important that the list of members is accurately updated. However, there would be the suspicion that the person who enlists or takes control of the list will determine who participates in the process or not. It will be needed, therefore, that the parties have a refined and accurate process to take into consideration the new members and to write down the persons who have quitted the party. Organization secretaries must be extremely cautions in the maintaining of the membership record, give the records the publicity needed and establish the procedures to correct the mistakes that could be made in the inscription of members.

It is been said that within the parties, party members tend to formalize a decision about candidates that has already been taken by obscure or non-transparent bodies of the party. However, this aspect is changing and likely to keep on changing through the years, broadening the selectorate and opening the parties to aliens, in order to stop the decrease in membership that parties are suffering (Gallagher, 1988a; Scarrow et al., 2000). And, even parties are not willing to open their internal procedures to aliens, they can be tempted to let the whole membership to participate in the nomination process. Whatever the reason is, the broadening of the selectorate will achieve a larger number of people deciding who will run for election and one can hope that this will increase the quality of our political representation and decrease the critics of closed circuit and elitism that the internal political life of parties receive (Hopkin, 2001). What is yet to be demonstrated is that extending to aliens the possibility to participate in the nomination process affects the membership, as it's been observed that citizens don't bother to affiliate a party in order to enjoy other benefits recognized to members (Hazan \& Rahat, 2006).

The composition of the selectorate can affect the profile of the candidate elected. It's said that when only party members participate in the nomination process, candidates tend to be more ideological and not responding, necessarily, to the preferences of the general electorate 
(Gallo, 2005). If party sympathizers participate we'd have the same result, as the ones mobilized would be people strongly ideologized (Kanthak \& Williams, 2005). If the membership is very homogeneous they could make the same choices than the executive of the party. Small and exclusive selectorates tend to designate candidates, that means, take into consideration their personal features.

If the selection is made by the general electorate, the candidate will represent a medium voter, but not the specific interests of the party members, which can affect to the internal cohesion of the party (Freidenberg \& Sanchez Lopez, 2002)Flavia; Sanchez Lopez, Francisco . Another risk to party cohesion are the cross voters, people who participate in the internal affairs of other party, but to take the chance to harm the party that has opened its process. Open primaries, for instance, could be invaded by political rivals who will try to choose a weak candidate (Borden, 2001; Kanthak \& Williams, 2005).

An open selectorate could facilitate the identification and inclusion of new political issues on the political agenda. However, it is feared that only the most flashy and attractive issues are discussed and not the basic ones, needed for the normal functioning of the system. That is, it is feared that demagogic candidates can make their stand. At the same time, broad and inclusive selectorates can extinguish the amateur politician (Pennings \& Hazan, 2001).

Open and inclusive selectorates are expected to increase the electoral competition (Kanthak \& Williams, 2005; Rossi \& Gori, 2009), although electoral data is yet to confirm this hypothesis, as primaries would function as a ballotaggio. In Chile a $10 \%$ participation was expected on the primaries and, at the end, it was a $36 \%$ of the general electorate who participated.

Open and inclusive selectorates are expected to increase the electoral competition (Kanthak \& Williams, 2005; Rossi \& Gori, 2009), although electoral data is yet to confirm this hypothesis, as primaries would function as a ballotaggio. In Chile a $10 \%$ participation was expected on the primaries and, at the end, it was a $36 \%$ of the general electorate who participated.

Does the selector have to be an elector? If the parties are the ones that determine the composition of the selectorate, they could extend the participation not only to voters, but to other sectors of population, such as minors or aliens (Rossi \& Gori, 2009). It is more difficult to justify this broadening when is the legislator who regulates the nomination process.

\section{e) PRACTICAL ASPECTS OF THE NOMINATION PROCESS:}

\section{Calendar}

When to call the nomination process? This is not a problem in a presidential system, but it could be a problem in a parliamentarian one. In a presidential system, nomination takes place near the electoral process. In a parliamentarian system, it could either take place a few months before the general election - and in this case is clearly an electoral related process - or after the general election, in order to legitimate the leader of the opposition if there have been bad results for his or her party. As in a parliamentary system elections can be held in any given moment, wait to the elections can be a bad strategy for a political party. Moreover, as a Prime Minister can be removed from office and substituted, having an alternative is not a bad idea. However, if the party leader and the electoral candidate are not the same person, a double leadership situation, and the consequent tensions, can be produced. 


\section{Political campaign}

Who can participate in the internal political campaign? This question is relevant in systems, as the Spanish one, that not contemplate the possibility that others than electoral competitors can ask the selectors for their vote. The more open the process is, the more similar and ambiguous the electoral messages will tend to be (Boix, 1998). If there are no relevant differences between candidates or in their electoral messages, nomination will end up being a "beauty pageant".

Normally, political parties ask the competitors to sign a commitment not to use negative campaign or diminish their rivals, in order not to weaken the possible candidate of the party and not to lose cohesion on the road.

An open nomination process implies that contestants will have to address the members, but also conduct an external image campaign. That brings us back to the funding of the process, as it will have to be paid by someone. Together with a regulation of the political campaign, there has to be a consideration about party funding of the campaign and even expenditure limits and/or control.

\section{How does the selectorate express its preferences?}

The selector ate will participate directly if it chooses the candidature without any intermission and indirectly if it chooses delegates or the members of the committee that will select the candidates. Indirect nomination processes favor "pre-cooked" candidatures by the apparatus, that converts the whole process in a non-competitive one. However, indirect methods of participation can conciliate alien participation and the concerns about the internal life of the party or it's cohesion. Following this line of reasoning, there will be voting when the candidature is fixed through the votes and not when it will be the ratification of a single list decided by some other body of the party (Hazan \& Rahat, 2006). The results of the voting must be presented in an official manner to justify and legitimate the candidate.

If voting is comprised, the party or the legislator will have to decide the kind of electoral system (majoritarian or proportional), the electoral formula, how many rounds, a participation threshold to validate the results, if the candidate has to obtain at least a $50 \%$ of the support... (Rossi \& Gori, 2008).

\section{Formal act of nomination?}

The last consideration of the organization of the nomination process will be how will the party let know the result and present the candidate to the public. A Convention can restore the cohesion of the party after the competition and give an opportunity to the candidate to influence in the electoral manifest or in the rest of the electoral list.

\section{DISCUSSION}

Whether is determined by the political party itself or the Legislature, the requirements imposed on the nomination process affects the right to be a candidate in a formal electoral process. Therefore, to stand as a pre-candidate on a nomination process is a necessary condition to become a candidate and thus can be said it falls within the scope of the fundamental right to be a candidate. Requirements imposed must be studied through the proportional principle and looking for the higher effectiveness of its content. 
Participating in a nomination process can be seen as an aspect of political participation of citizens. Right now, most of the countries are considering this question an internal issue of political parties. Consequently, they are broadening the public allowed to participate, so the selectorate doesn't match the electorate. If nomination is considered part of the electoral process is difficult not to justify the intervention of the state. However, it is not certain that this should mean the opening of the nomination process to every citizen, as it can breach the right of association of a political party and their members. That being said, some other ways, like in Chile or lately in Norway, can be found to promote the opening to the nomination process. It is true that, perhaps, before considering the opening to all the citizens - or even beyond -, one must assure that all the party members have an actual right to participate in the nominations process that they conduct. I found this solution correct as it respects the party right to chose its own organization, and thus decide the extent of the participation, and allows the intervention of the State over the nomination process and, for instance, extend the guarantees of the electoral process.

Where political parties are strong, nominations tend to be seen as an internal affair and regulated mainly by the own political parties. This is the case of France, Italy or Spain. In some other countries, nominations are seen as part of the electoral process and the Legislature has established some previsions, as in United States, Argentina or Chile. Either way, the regulations have to be consistent and promote transparent and participative processes.

Nominations systems have to be consistent with the political and electoral system. That's why I'm not a big fan of primaries for parliamentary systems with proportional electoral systems. The Italian experience makes a good point. However, normally in every country are a variety of electoral systems (national, regional, local) and different nomination models can be experimented.

In order to set a nomination process, funding is essential. Although the French and Italian primaries were self-funded, a party cannot count on it for ever, as the Spanish case points out. Massive participation - due not only to the nomination process, but to the electoral expectations - shan't be taken for granted. Democracy costs money and if the population of a country thinks that they should adopt more inclusive nomination process, it has to be willing to pay for them. If the party is paying, it can explore other alternatives, such as demand a percentage of the donations that receive the candidates.

As for some more practical aspects of the nomination process, when to hold the selection process is relevant. It depends on the political system, and the different roles that an electoral leader can play (electoral leader, head of the opposition, party leader). If nomination is not included in the electoral calendar, that can create a problem for parties that have waited too much to hold a primary.

The use or access to the official Electoral Census or list is relevant when the selectorate of the nomination process coincides with the electorate, that is, that minors or some foreigners are not allowed to participate. The Electoral Census provides a guarantee of the composition of the deciding body and it isn't easily manipulated.

When using public-owned voting places, the nomination process replicates the electoral system and underlines its electoral aspect and public relevance. However, the nomination process shall be considered part of the electoral process to ease this situation. The same happens with political campaign of the nominations that can be restricted according to electoral provisions. 
If the nomination campaign is too restricted, voters could not have information enough to cast their ballot and the nomination will end up being a beauty contest. However, is in the interest of party cohesion to diminish negatives campaigns or attacks between contestants.

In the cases studied, there was the nomination of just one candidate. Therefore, in all of them a majoritarian electoral formula was used. Can this be used to compose an electoral ticket? Perhaps other nomination models must be used to form an electoral ticket.

Both the theoretical mark and the cases exposed present a list of considerations that anyone regulating a nomination process should take into account, also considering the relevant role that the selection of electoral candidates plays in a representative democracy.

\section{BIBLIOGRAPHY}

Barberà, Ó., Baras, M., Barrio, A., \& Rodríguez Teruel, J. (2008). Are parties democratizing themselves? The evolution of leadership selection in Spain (1977-2008) (No. 285) (p. 26). Barcelona.

Barberà, Ó., \& Rodríguez Teruel, J. (2012). The introduction of party primaries in Spain. In Party primaries in Europe. Consequences and challenges (pp. 1-19). Antwerp.

Barrat i Esteve, J. (1995). Los procesos de seleccion de candidatos en los partidos politicos. Cuadernos de La Catedra Fadrique Furio Ceriol, 13, 95-142.

Bille, L. (2001). Democratizing a Democratic Procedure: Myth or Reality?: Candidate Selection in Western European Parties, 1960-1990. Party Politics, 7(3), 363-380. doi:10.1177/1354068801007003006

Boix, C. (1998). Las elecciones primarias en el PSOE. Claves de Razon Practica, 83, 34-38.

Borden, C. E. (2001). Primary elections. Harvard Journal on Legislation, 38, 263-278.

Bott, A. J. (1990). Handbook of United States Election Laws and Practice. Political rights. Nueva York: Greenwood Press.

Ceaser, J. W. (2004). Political parties and presidential ambition. In E. H. Buell Jr. \& W. G. Mayer (Eds.), Enduring controversies in Presidential nominating politics. Pittsburgh: University of Pittsburgh Press.

Christensen, A. N., \& Kirkpatrick, E. M. (1950). The people, politics, and the politician. Nueva York: Henry Holt and Company.

Claude, R. (1970). The Supreme Court and the Electoral Process. Baltimore: The Jonhs Hopkins Press.

Dalton, R. J., \& Wattenberg, M. P. (2000). Parties without partisans: political change in advanced industrial democracies (p. 314). New York etc.: Oxford University Press. 
De Vega García, A. S. (1989). Derecho de partidos y democracia interna en el ordenamiento español. Debate Abierto, (1).

Epperson, J. W. (1986). The changing legal status of political parties in the United States. Nueva York: Garland publishing.

Epstein, L. D. (1981). Political parties: Organization. In H. R. Penniman, A. Ranney, \& D. Butler (Eds.), Democracy at the polls: A comparative study of competitive national elections. Washington D. C.: American Enterprise Institute for Public Policy Research.

Federal Electoral Commission. (1988), Ballot acces I. Issues and options. Washington D. C.: Federal Electoral Commission.

Flores Giménez, F. (2000). La posición constitucional de los partidos políticos no es lo que era. In E. Espín Templado \& F. J. Díaz Revorio (Eds.), La justicia constitucional en el Estado democrático, Ed. Tirant lo Blanch, Valencia, 2000. Valencia: Tirant lo blanch.

Freidenberg, F., \& Sanchez Lopez, F. (2002). ¿Como se elige un candidato a presidente? Reglas y practicas en los partidos politicos de America Latina. Revista de Estudios Políticos, 118, 321.

Fusaro, C. (2003). Elezioni primarie, problemi di una disciplina pubblicistica. Quaderni Costituzionali, 23(1), 140-143. Retrieved from http://eprints.uniss.it/239/

Galeotti, S. (1983). I partiti politici. In Verso una nuova Costituzione. Milán: Giuffrè.

Gallagher, M. (1988a). Conclusion. In M. Gallagher \& M. Marsh (Eds.), Candidate selection in comparative perspective. The secret garden of politics (pp. 236-283). London: Sage Publications.

Gallagher, M. (1988b). Introduction. In M. Gallagher \& M. Marsh (Eds.), Candidate selection in comparative perspective. The secret garden of politics. London: SAGE Publications.

Gallagher, M., \& Marsh, M. (Eds.). (1988). Candidate selection in comparative perspective. The secret garden of politics. London: SAGE Publications.

Gallo, A. (2005). Mecanismos de seleccion partidaria y legitimidad de las candidaturas. El debate en Latinoamerica. Revista de Investigaciones Politicas Y Sociologicas, 4(2), 277-289.

Gambino, S., \& Moschella, G. (1997). Democracia de los partidos y democracia en los partidos: la conveniencia de las elecciones primarias. Revista Vasca de Administración Pública, (48).

Hazan, R. Y., \& Rahat, G. (2006). Candidate selection: methods and consequences. In R. S. Katz \& W. J. Crotty (Eds.), Handbook of party politics. Londres: Sage Publications.

Hazan, R. Y., \& Rahat, G. (2010). Democracy within parties. Candidate selection methods and their political consequencese (p. 212). Oxford: Oxford University Press. 
Hopkin, J. (2001). Bringing the members back in?: Democratizing candidate selection in Britain and Spain. Party Politics, 7(3), 343-361. doi:10.1177/1354068801007003005

Janda, K. (2005). Adopting party law (p. 38). Washington D. C.

Kanthak, K., \& Williams, J. (2005). Parties and primaries: The first electoral round. In M. J. Streb (Ed.), Law and election politics. Boulder: Lynne Rienner Publishers.

Katz, R. S. (2001). The Problem of Candidate Selection and Models of Party Democracy. Party Politics, 7(3), 277-296. doi:10.1177/1354068801007003002

Katz, R. S. (2006). Party in democratic theory. In R. S. Katz \& W. J. Crotty (Eds.), Handbook of party politics. Londres: Sage Publications.

Kirchheimer, O. (1966). The transformation of the Western European Party systems. In J. LaPalombara \& M. Weiner (Eds.), Political parties and political development. Princeton: Princeton University Press.

López Nieto, L. (2007). Los nuevos apellidos de la democracia: retos de la participación dirigida o mediatizada en España. Cuadernos de Pensamiento Político, (13).

Maroto Calatayud, M. (2008). Autorregulación y legitimidad corporativa: democracia interna y control social en partidos políticos y empresas. In L. Arroyo Jimenez \& A. Nieto Martin (Eds.), Autorregulacion y sanciones. Valladolid: Lex Nova.

Martinez Sospedra, M. (1996). Introducción a los partidos políticos. Barcelona: Ariel.

Montero, J. R., \& Gunther, R. (1994). Sistemas "cerrados" y listas "abiertas": sobre algunas propuestas de reforma del sistema electoral en España. Cuadernos Y Debates, (49).

Müller, W. C., \& Sieberer, U. (2006). Party law. In R. S. Katz \& W. J. Crotty (Eds.), Handbook of party politics. Londres: Sage Publications.

Navarro Méndez, J. I. (1999). Partidos políticos y democracia interna. Madrid: CEPC.

Norris, P. (2006). Recruitment. In R. S. Katz \& W. J. Crotty (Eds.), Handbook of party politics. Londres: Sage Publications.

Olson, M. (1986). Auge y decadencia de las naciones (p. 332). Barcelona: Ariel.

Ostrogorski, M. (1979). La democratie et les partis politiques ( $2^{\mathrm{a}} \mathrm{ed}$.). Paris: Editions du Seuil.

Pedrazza Gorlero, M. (1992). Libertà costituzionali e democrazia interna nelle formazioni sociali. Diritto E Società, (2). 
Pennings, P., \& Hazan, R. Y. (2001). Democratizing candidate selection: Causes and consequences. Party Politics, 7(3), 267-275. doi:10.1177/1354068801007003001

Pinelli, C. (1984). Discipline e controlli sulla democrazia interna dei partiti. Padua: CEDAM.

Rahat, G., \& Hazan, R. Y. (2001). Candidate selection methods: An analytical framework. Party Politics, 7(3), 297-322. doi:10.1177/1354068801007003003

Rahat, G., \& Hazan, R. Y. (2007). Political participation in party primaries. Increase in quantity, decrease in quality? In T. Zittel \& D. Fuchs (Eds.), (p. 57). London etc.: Routledge.

Ranney, A. (1965). Pathways to Parliament. Candidate selection in Britain. Londres: Macmillan.

Ranney, A. (1981). Candidate selection. In H. R. Penniman, A. Ranney, \& D. Butler (Eds.), Democracy at the polls: A comparative study of competitive national elections. Washington D. C.: American Enterprise Institute for Public Policy Research.

Rescigno, G. U. (1982). Limitare il sovrano: brevi note sui partiti politici. Critica Del Diritto, (27-28).

Rescigno, G. U. (1984). Potere politico e sistema dei partiti: limitare il sovrano. Politica Del Diritto, 15(1).

Roberts, G. (1988). The German Federal Republic: the two-lane route to Bonn. In M. Gallagher \& M. Marsh (Eds.), Candidate selection in comparative perspective. The secret garden of politics (pp. 94-118). London: SAGE Publications.

Rossi, E., \& Gori, L. (2008). Le elezioni primarie come forma di partecipazione alla vita politica italiana: un primo bilancio dopo dieci anni di «esperimenti». Revista Catalana de Dret Públic, (37), 75-128.

Rossi, E., \& Gori, L. (2009). Le "primarie" in Italia: dalla prassi alle regole, Quaderni Costituzionali, 29(3).

Scarrow, S. E. (1996). Parties and their members: organizing for victory in Britain and Germany (p. 277). Oxford etc.: Oxford University Press.

Scarrow, S. E., Webb, P., \& Farrel, D. M. (2000). From social integration to electoral contestation. In R. J. Dalton \& M. P. Wattenberg (Eds.), Parties without partisans. Oxford: Oxford University Press.

Schattschneider, E. E. (2004). What the political parties are not. In E. H. Buell Jr. \& W. G. Mayer (Eds.), Enduring controversies in Presidential nominating politics. Pittsburgh: University of Pittsburgh Press. 
Valen, H. (1988). Norway: decentralization and group representation. In M. Gallagher \& M. Marsh (Eds.), Candidate selection in comparative perspective. The secret garden of politics (pp. 210-235). London: SAGE Publications.

Wagner, A., \& Weßels, B. (2012). Parties and their Leaders. Does it matter how they match? The German General Elections 2009 in comparison. Electoral Studies, 31(1), 72-82. doi:10.1016/j.electstud.2011.06.007

Ware, A. (2004). Partidos políticos y sistemas de partidos. Madrid: Istmo. 
Recebido em: 08/11/2015

Aceito em: 01/03/2016

\section{Como citar}

PÉREZ-MONEO, Miguel. Regulating nominations in political parties:

Candidates, open primaries and Law. Ballot. Rio de Janeiro: UERJ.

Volume 2 Número 1 Janeiro/Abril 2016. pp. 27-54. Disponível em:

[http://www.e-publicacoes.uerj.br/index.php/ballot]

\section{(c) (1) $\$(0)$}

A Revista Ballot está licenciada sob uma licença Creative Commons Atribuição - Não Comercial - Compartilha Igual 3.0 Não Adaptada. 